3. Бернадинер М.Г., Ентов В.М. Гидродинамическая теория фильтрации аномальных жидкостей. М.: Недра, 1975. 100 с.

4. Бэр Я., Заславский Д., Ирлой С. Физико-математические основы фильтрации воды. М.: Мир, 1971. 451 с.

5. Лейбензон Л.С. Движение природных жидкостей и газов в пористой среде. М.: ОГИЗ, 1947. 156 с.

6. Гольдбер, В.М., Скворцов Н.П. Теория фильтрации. М.: Недра, 1986. $102 \mathrm{c}$.

7. Левашкевич В.Г. Нелинейные эффекты при фильтрации жидкости в пористой среде. Минск: Наука и техника, 1987. 102 с.

8. Маскет М. Течение однородных жидкостей в пористой среде. М. : Гостоптехиздат, 1949.94 с.

9. Бондаренко Н.Ф. Физика движения подземных вод. Ленинград, 1979. $214 \mathrm{c}$.

10. Пат. 142935 Україна, МПК (2020.01) В09С 1/00, В09С 1/10 (2006.01), C02F 3/32 (2006.01). Спосіб осушення сховищанакопичувача рідких відходів підприємств / А.Ф.Булат, М.С. Терещук, Є.В. Семененко, Т.Д. Демченко, Т.Д. Клокова № u201910678; Заявл. 28.10.2019; Опубл. 10.07.2020, Бюл № 13.

11. Полубаринова-Кочина П.Я. Теория движения грунтовых вод. М.: Наука, 1977. 664 с.

DOI https://doi.org/10.30525/978-9934-588-79-2-2.12

\title{
ПІДБІР КОМПОНЕНТІВ У СКЛАДІ ДЕРМАТОЛОГІЧНОГО ЗАСОБУ 3 ПРОБІОТИКОМ
}

\author{
Соловйова А. В. \\ аспірант кафедри біотехнологіi \\ Національного фармацевтичного університету \\ Калюжная О. С. \\ кандидат фармацевтичних наук, \\ дочент кафедри біотехнологіi \\ Національного фармацевтичного університету \\ м. Харків, Україна
}

Акне - одне з найпоширеніших захворювань людства, хронічне захворювання сальних залоз, яке переважно проявляється в період статевого дозрівання і характеризується гіперпродукцією шкірного сала, 
порушенням процесів фолікулярного ороговіння, колонізацією Cutibacterium acne та запаленням [1, с. 110, 3, с. 272]. Незважаючи на великий асортимент ліків, поки що немає жодного однозначно ефективного засобу для лікування акне [4, с. 148]. Недостатня увага приділяється мікробіологічним основам шкіри, хоча роль мікрофлори шкіри неможливо переоцінити [2, с. 44]. Тому перспективним підходом до лікування акне є використання комплексного засобу з пробіотичними та антимікробними речовинами та компонентами, які одночасно пригнічують збудник та умовно-патогенну мікрофлору, лікуючи запалення та усуваючи надлишки шкірного сала. В якості пробіотичного компоненту був обраний штам Lactobacillus plantarum B-2693. В якості антимікробного та антисептичного компонента були обрані такі компоненті: масло календули, лаврове масло, гірчичне масло та масло чайного дерева, танін, гідроксикислоти - молочна кислота (АНА), саліцилова кислота (ВНА) та азелаїнова кислота [4, с. 147]. Для визначення можливості використання штамів пробіотиків з антимікробним компонентом у складі однієї лікарської форми було проведено спільне культивування штамів пробіотиків з певним антимікробним інгредієнтом у певних концентраціях.

За результатами біотехнологічних досліджень щодо можливості спільного використання пробіотиків з антимікробними та протизапальними компонентами (базові та ефірні олії, кислоти АНА та ВНА, азелаїнова кислота та танін), для подальших досліджень з розробки комплексного лікувально-профілактичного протиугревого засобу були відібрані штами молочнокислих бактерій (початкова доза $10^{9}$ КУО), масло календули (концентрація 0,1%), молочна кислота (концентрація $0,01 \%$ ). Остаточний вибір концентрацій пробіотичного штаму та вибраних активних компонентів буде залежати від подальших досліджень їх комплексної дії на умовно-патогенних мікроорганізмів, як факторів інфекційних дерматологічних захворювань, включаючи інфекційну форму акне.

\section{Література:}

1. Аравийская Е. Р., Соколовский Е.В. Комбинированные препараты в наружном лечении акне: современные данные : Вестник дерматологии и венерологии. 2012. № 3. С. 110-114.

2. Багмет А.Н., Шаповалова О.В. Коррекция нарушений микробиоценоза кожи при легких формах угревой болезни : Дерматол. и венерол. 2003. № 1 (19). С. 44-46. 
3. Adityan B., Thappa D. Profile of acne vulgaris a hospital-based study from South India : Indian Journal Dermatol Venereol Leprol. 2009. № 75. P. 272-278.

4. Layton A., Zeichner J. Top ten list of clinical perls in the treatment of acne vulgaris : Advances in acne management. 2016. № 2. P. 147-152.

DOI https://doi.org/10.30525/978-9934-588-79-2-2.13

\title{
БІОТЕХНОЛОГІЧНЕ ТЕСТУВАННЯ ЗА ДОПОМОГОЮ НАЙПРОСТІШИХ
}

\author{
Стрілець О. П. \\ доктор фармачевтичних наук, \\ професор кафедри біотехнології \\ Національного фармацевтичного університету \\ Стрельников Л. С. \\ доктор фармачевтичних наук, \\ професор кафедри біотехнологіi \\ Національного фармацевтичного університету \\ м. Харків, Україна
}

В останні роки стала актуальною розробка нових експрес-методів оцінки різних біологічних об'єктів, включаючи продукти харчування, кормові добавки, косметичні засоби, тощо. На даному етапі розвитку науки численні дослідники віддають перевагу інноваціям в області біотестування, інтенсивний розвиток якого почався у 1950-х рр минулого століття, і продовжується зараз. Практика використання найпростіших (Protozoa) в якості тест-організмів нараховує не одне десятиліття [1, с. 49].

Вперше законодавчо біотестування було уведено у радянські часи у другій половині 20-го століття, яке використовувалось для контролю стічних і природних вод.

У теперішній час біотестування затребуване у самих різних областях: біотехнології, медицині, ветеринарії, екотоксикології, фармації, косметології, хімії. Об'єктом біотехнологічного тестування може бути люба продукція рослинного, тваринного, синтетичного і навіть генетично-модифікованого походження [3, с. 28]. 